\title{
IbM Promkes pencegahan Covid-19 pada anak di TK Aba An Nur Bantul Yogyakarta
}

\author{
Herlin Fitriani Kurniawati ${ }^{1 *}$, Herlin Fitriana Kurniawati ${ }^{2}$ \\ 1,2Universitas 'Aisyiyah Yogyakarta
}

\section{INFORMASI ARTIKEL:}

\begin{tabular}{l}
\hline Riwayat Artikel: \\
Tanggal diterima: 25 Juni 2021 \\
Tanggal direvisi: 20 Juni 2021 \\
Tanggal dipublikasi: 30 Juni 2021 \\
\hline
\end{tabular}

Kata kunci:

Pencegahan

Covid 19

Anak

Keyword:

Prevention

Fovid 19

Children

\section{ABSTRAK}

Latar Belakang : Virus corona atau Severe Acute Respiratory Syndrome Coronavirus 2 (SARS-CoV-2) adalah virus yang menyerang sistem pernapasan. Penyakit karena infeksi virus ini disebut COVID-19. Virus Corona bisa menyebabkan gangguan ringan pada sistem pernapasan, infeksi paru-paru yang berat, hingga kematian. Virus corona adalah jenis baru dari coronavirus yang menular ke manusia. Walaupun lebih bayak menyerang lansia, virus ini sebenarnya bisa menyerang siapa saja, mulai dari bayi, anak-anak, hingga orang dewasa, termasuk ibu hamil dan ibu menyusui. Permasalahan : Jumlah kasus Virus Corona di DIY sebagaimana dirilis Situs Resmi DIY Tanggap COVID19 hingga Rabu 15 April 2020 pukul 16.00 WIB, Berdasarkan hasil lab, 62 orang dinyatakan positif (22 orang sembuh, 6 orang meninggal dunia), 244 orang dinyatakan negatif, dan masih menunggu hasil lab sebanyak 275 orang (14 orang meninggal dunia). Sementara itu, total ODP yang tersebar di seluruh DIY yakni 3.652 orang. Solusi : Pemberian promosi kesehatan tentang Covid 19. Metode : Kegiatan pemberian informasi tentang pencegahan Covid 19 di TK ABA An Nur belum banyak dilakukan salah satunya dikarenakan kendala interaksi dengan wali murid yang dibatasi dengan adanya social distancing. Luaran : peningkatan pengetahuan tentang pencegahan Covid 19 pada Anak di TK ABA An Nur Bantul Yogyakarta tentang pengertian Covid-19, mengenali gejala Covid-19, tanda dan gejala Covid-19, cara mengetahui nafas cepat pada anak, penanganan jika suhu anak mencapai $38^{\circ} \mathrm{C}$ atau lebih, pembatasan social distacing, cara mencegah Covid-19, rekomendasi terkait masalah pada anak agar tidak Terpapar Covid-19, etika batuk dan bersin yang benar dan cara mencuci tangan yang benar tersedianya booklet tentang pencegahan Covid 19 pada anak sebagai pegangan dalam memberikan informasi kepada orang tua wali siswa TK ABA An Nur, hasil pengabdian masyarakat akan di publikasikan pada prosiding tingkat nasional atau jurnal nasional

Background: Coronavirus or Severe Acute Respiratory Syndrome Coronavirus 2 (SARS(oV-2) is a virus that attacks the respiratory system. The disease caused by this virus is called COVID-19. Coronavirus can cause mild disorders of the respiratory system, severe lung infections, and even death. Coronavirus is a new type of coronavirus that is transmitted to humans. Although it mostly affects the elderly, this virus can attack anyone, from infants, children, adults including pregnant women and breastfeeding mothers. Problem: The number of Coronavirus cases based on the lab results in DIY as released by the DIY COVID-19 Response Official Site until Wednesday, April 15th, 2020 at 4.00 p.m. were 62 people declared positive ( 22 people recovered, 6 people died), 244 people were declared negative, and still waiting for lab results, and 275 people (14 people died). Meanwhile, the total number of people under surveillance (PUS) were 3,652 people. Solution: Providing health promotions about Covid 19. Method: Providing the information about the prevention of Covid 19 at ABA An-Nur Kindergarten which has not been widely carried out. This problem, one of which is caused by the obstacles in interacting with parents who are limited by social distancing. Result: The increase of the knowledge about the prevention of Covid 19 in children at ABA An-Nur Kindergarten Bantul Yogyakarta including the meaning of Covid-19, recognizing Covid-19 symptoms, signs and symptoms of Covid-19, how to indicate the fast breathing of the children, handling the children when the temperature reaches $38{ }^{\circ} \mathrm{C}$ or more, social distancing restrictions, ways to prevent Covid-19, recommendations regarding problems in children so as not to be exposed to Covid-19, correct coughing and sneezing etiquette and proper handwashing, availability of booklets on preventing Covid 19 in children as a guide in providing information to parents and guardians of ABA An-Nur Kindergarten students, the results of community service will be published in national-level proceedings or national journals 


\section{Pendahuluan}

Virus corona atau Severe Acute Respiratory Syndrome Coronavirus 2 (SARS-CoV-2) adalah virus yang menyerang sistem pernapasan. Penyakit karena infeksi virus ini disebut COVID-19. Virus Corona bisa menyebabkan gangguan ringan pada sistem pernapasan, infeksi paru-paru yang berat, hingga kematian. Virus corona adalah jenis baru dari coronavirus yang menular ke manusia. Walaupun lebih bayak menyerang lansia, virus ini sebenarnya bisa menyerang siapa saja, mulai dari bayi, anak-anak, hingga orang dewasa, termasuk ibu hamil dan ibu menyusui (Pane, 2020, diperoleh tanggal 27 April 2020).

World Health Organization (WHO) menetapkan virus corona sebagai sebuah pandemi. Selain itu, ada sebutan lain yang kerap dihubungkan dengan COVID-19 ini seperti epidemi dan wabah. Wabah penyakit yang masuk dalam kategori pandemi adalah penyakit yang menular dan memiliki garis infeksi berkelanjutan. Jadi, jika ada kasus terjadi di beberapa negara lainnya selain negara asal, digolongkan sebagai pandemi (Hermawan, 2020, diperoleh tanggal 20 April 2020). Pandemi virus corona di Indonesia diawali dengan temuan penderita penyakit Coronavirus 2019 (COVID-19), pada tanggal 2 Maret 2020. Kasus kejadiannya hingga 19 Juni 2020, telah terkonfirmasi 42.762 kasus positif COVID-19 dengan 23.625 kasus dirawat, 16.798 kasus sembuh, dan 2.373 kasus meninggal. Sebagai tanggapan terhadap pandemi ini, beberapa wilayah telah memberlakukan pembatasan sosial berskala besar (PSBB) (www.id.wikipedia.org, diperoleh tanggal 19 Juni 2020).

Corona Virus Disease 2019 atau COVID-19 adalah penyakit menular yang disebabkan oleh SARS-CoV-2, salah satu jenis koronavirus. Penderita COVID-19 dapat mengalami demam, batuk kering, dan kesulitan bernafas. Infeksi menyebar dari satu orang ke orang lain melalui percikan (droplet) dari saluran pernapasan yang sering dihasilkan saat batuk atau bersin. Jarak jangkauan droplet biasanya hingga 1 meter. Droplet bisa menempel di benda, namun tidak akan bertahan lama di udara. Waktu dari paparan virus hingga timbulnya gejala klinis antara 1-14 hari dengan rata-rata 5 hari. Maka, bagi

\footnotetext{
* Korespondensi penulis.

Alamat E-mail: herlinan@unisayogya.ac.id
}

orang yang sedang sakit diwajibkan memakai masker guna meminimalisir penyebaran droplet.

Hal terpenting yang saat ini harus dilakukan masyarakat adalah menjaga kesehatan, baik secara fisik maupun mental. Kementerian Kesehatan menerbitkan Pedoman Penanganan Cepat Medis dan Kesehatan Masyarakat Covid-19 di Indonesia untuk memberikan panduan apa yang harus dilakukan masyarakat di saat Covid-19 menjadi ancaman. Untuk menjaga kesehatan secara fisik dan meningkatkan daya tahan tubuh selama wabah masih meluas, Kemenkes memberikan pedoman untuk masyarakat yang dapat meningkatan imunitas tubuh atau fisik, di antaranya konsumsi gizi seimbang, aktivitas fisik atau senam ringan, istirahat cukup, mengonsumsi suplemen vitamin, tidak merokok, menggunakan masker, serta mengendalikan penyakit penyerta, seperti diabetes melitus, hipertensi, dan kanker (Kemenkes, 2020).

Pemerintah mencatat jumlah pasien positif Covid-19 di Indonesia hingga 15 April 2020 pukul 15.00 WIB mencapai 5.136 kasus Dari jumlah itu, 469 orang meninggal dunia dan 446 orang dinyatakan telah sembuh (Kemenkes, 2020). Jumlah kasus Virus Corona di DIY sebagaimana dirilis Situs Resmi DIY Tanggap COVID-19 hingga Rabu 15 April 2020 pukul 16.00 WIB, Berdasarkan hasil lab, 62 orang dinyatakan positif (22 orang sembuh, 6 orang meninggal dunia), 244 orang dinyatakan negatif, dan masih menunggu hasil lab sebanyak 275 orang (14 orang meninggal dunia). Sementara itu, total ODP yang tersebar di seluruh DIY yakni 3.652 orang. Tiga PDP yang meninggal masing-masing, bayi perempuan warga Sleman berusia 10 hari, meninggal pada 13 April 2020. Bayi laki-laki warga Sleman berusia satu tahun meninggal pada 15 April. Dan terkahir meninggal hari ini perempuan berusia 47 tahun warga Bantul. Bayi 1 (usia 10 hari) ada penyakit meningitis, tapi tidak ada riwayat luar daerah. ada gejala pneumonia sehingga masuk PDP. Bayi 2 (usia 1 tahun) ada kontak orang tua kerja di klaten, dan ada gejala klinis, sehingga masuk PDP.

Pandemi Covid-19 saat ini sedang berlangsung di Indonesia, tidak henti-hentinya pemerintah, kepala daerah, hingga pengurus RT/RW menyerukan kepada warganya agar tetap di rumah. Namun, hingga hari ini masih tampak warga 
yang beraktivitas di luar rumah dan tetap mengemudikan kendaraan di jalan raya. Pembatasan jarak fisik melalui gerakan physical distancing dan social distancing sejak 16 Maret 2020 lalu sudah tampak dengan perubahan pola belajar di rumah bagi siswa dan bekerja dari rumah (work from home) bagi karyawan, baik negeri maupun swasta (Kemenkes, 2017). Dari hasil observasi tersebut penulis, masyarakat terutama yang mempunyai anak balita belum semua menerapkan pencegahan penularan covid-19 pada anak balita dengan baik.

Masyarakat diharapkan menerapkan rinsipprinsip pencegahan COVID-19 meliputi universal precaution dengan selalu cuci tangan memakai sabun selama 20 detik atau hand sanitizer, pemakaian alat pelindung diri, menjaga kondisi tubuh dengan rajin olah raga dan istirahat cukup, makan dengan gizi yangseimbang, dan mempraktikan etikabatuk-bersin (Kementrian Kesehatan Republik Indonesia, 2020). Masyarakat juga dihimbau untuk mengikuti petunjuk pemerintah dengan ketat dan membatasi tatap muka dengan teman dan keluarga, khususnya jika: berusia 60 tahun keatas, memiliki penyakit komorbid (penyakit penyerta) seperti diabetes melitus, hipertensi, kanker,asma dan Penyakit Paru Obstruksi Kronik (PPOK) dan lain-lain serta ibu hamil (Kemenkes, 2020).

Dengan adanya kegiatan pemberian informasi tentang pencegahan penularan covid 19 pada anak dimaksudkan untuk menyadarkan ibuibu yang memiliki anak dan balita untuk tetap menjaga perilaku untuk menghindarkan diri dari perilaku yang dapat menularkan Covid 19. Dalam kegiatan tersebut diharapkan pengetahuan ibu-ibu wali murid menjadi semakin luas sehingga dapat menjaga diri dan keluarganya dari penyakit tersebut.

Kegiatan pemberian informasi tentang pencegahan Covid 19 di TK ABA An Nur belum banyak dilakukan salah satunya dikarenakan kendala interaksi dengan wali murid yang dibatasi dengan adanya social distancing.

\section{Permasalahan Mitra}

Mitra dalam kegiatan ini adalah TK ABA An Nur, dengan permasalahan pada mitra meliputi:

a. Kurangnya pengetahuan ibu-ibu yang memiliki anak tentang Covid-19 b. Kepala Sekolah menginginkan edukasi berkaitan dengan Covid-9 kepada ibu-ibu wali murid yang harapannya dapat digunakan untuk edukasi orang tua kepada anaknya.

c. Kasus Covid-19 di DIY yang semakin hari semakin naik

d. Adanya keresahan masyarakat adanya informasi yang simpang siur berkaitan dengan Covid-19.

e. Tantangan sekolah untuk memulai kembali kegiatan di sekolah dengan konsep New Normal

\section{Metode Pelaksanaan}

Metode pelaksanaan untuk menyelesaikan masalah tersebut adalah melakukan pemberian informasi berkaitan dengan Covid-19 kepada guru dan wali murid di TK ABA An Nur. Kegitan yang dilakukan meliputi pendekatan kepada mitra, membuat booklet tentang Covid-19, koordinasi dengan Kepala Sekolah, koordinasi dengan guru pendamping di setiap kelas, pemberian informasi kepada wali murid di TK ABA An Nur melalui Whatsapp Group.

Adapaun rangkuman kegiatan yang telah dilakukan adalah sebagai berikut:

a. Koordinasi dengan Kepala Sekolah TK ABA An Nur

b. Mempersiapkan booklet tentang Covid 19

c. Koordinasi dengan guru kelas untuk pelaksanaan kegiatan pemberian informasi tentang Covid-19.

d. Pelaksanaan pemberian informasi tentang Covig-19.

e. Melakukan pemantauan pemberian informasi dengan guru kelas.

f. Menyusun laporan IbM dan mempublikasikan dalam kegiatan ilmiah.

\section{Hasil dan Pembahasan}

Pelaksanaan kegiatan IbM ini dilakukan melalui beberapa tahapan, mulai dari persiapan, pelaksanaan dan evaluasi.Tahap Persiapan dilakukan sebanyak satu kali, dalam bentuk kegiatan koordinasi dengan kepala Sekolah dan Guru kelas di TK ABA An Nur. Tahap persiapan, pengabdin masyarakat melakukan kegiatan meliputi menyusun materi tentang Covid-19, melakukan koordinasi dengan mitra, melakukan koordinasi tentang teknis pelaksanaan pengabdian masyarakat. Persiapan materi dan media promosi dengan membuat booklet. 

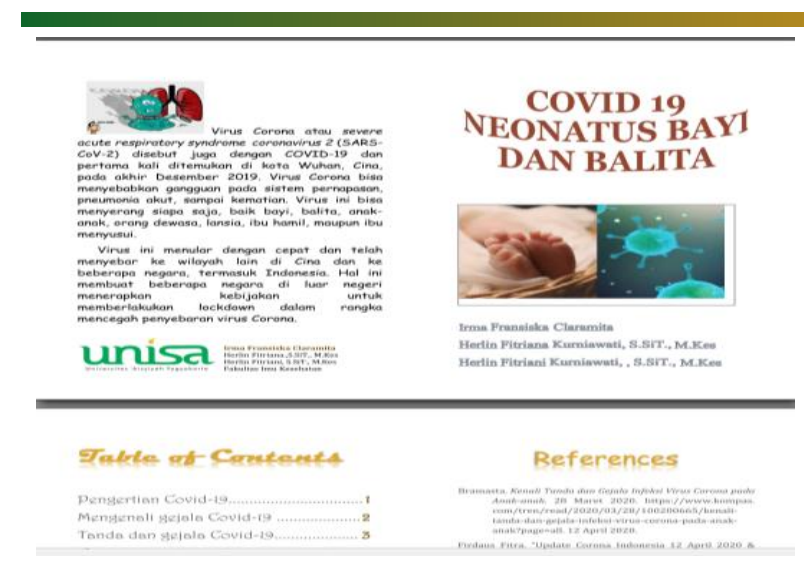

Gambar 1 Booklet Covid 19 Neonatus, Bayi dan Balita

Upaya tersebut merupakan salah satu bentuk pemberian pendidikan kesehatan dan promosi kesehatan, pada hakikatnya adalah suatu usaha atau kegiatan menyampaikan pesan kepada masyarakat, kelompok atau individu dengan harapan kelompok, masyarakat atau individu memperoleh pengetahuan tentang kesehatan yang lebih baik. Kegiatan pendidikan kesehatan memerlukan media pendidikan kesehatan yang berfungsi untuk mempermudah penerimaan pesan-pesan kesehatan bagi masyarakat (Machfoedz \& Suryani, 2009). Pendidikan kesehatan yang bertujuan merubah perilaku individu, kelompok dan masyarakat tidak cukup meningkatkan derajat kesehatan karena masih banyak faktor atau determinan yang memepengaruhi kesehatan diluar wilayah kesehatan. Determinan kesehatan tersebut tidak dapat diintervensi dengan pendidikan kesehatan tetapi memelukan regulasi, legislasi dan advokasi (Susilowati, 2016). Dalam mewujudkan promosi kesehatan yang paripurna perlu dilakukan strategi promosi kesehatan yang terdiri dari pemberdayaan, bina suasana, advokasi dan kemitraan (Kemenkes, 2011).

Pelaksanaan kegiatan pengabdian ini dengan melakukan koordinasi dengan pihak mitra yakni dengan Kepala Sekolah, sebagai penanggung jawab mitra. Koordinasi yang pertama kali dilaksanakan untuk menindaklanjuti kerja sama dengan mitra, bahwa TK ABA An Nur akan menjadi mitra kegiatan pengabdian. Koordinasi selanjutnya adalah pelaksanaan perijinan dengan penanggung jawab di TK ABA An Nur yakni dengan Kepala Sekolah. Kepala Sekolah telah memberikan ijin pelaksanaan kegiatan pengabdian dengan telah ditandatanganinya informed consent dan teknis pelaksanaan lebih lanjut diserahkan kepada Guru Kelas di TK ABA An Nur. Melakukan koordinasi tentang teknis pelaksanaan kegiatan, meliputi penjadwalan dan pembagian tugas antara pengabdi dan penanggung jawab karang taruna. Pelaksanaan Pemberian informasi tentang Covid-19 meliputi : Pengertian Covid-19, mengenali gejala Covid-19, tanda dan gejala Covid-19, cara mengetahui nafas cepat pada anak, penanganan jika suhu anak mencapai $38^{\circ} \mathrm{C}$ atau lebih, pembatasan social distacing, cara mencegah Covid-19, rekomendasi Terkait Masalah anak agar tidak Terpapar Covid-19, etika Batuk dan Bersin yang Benar dan cara Mencuci Tangan yang Benar.

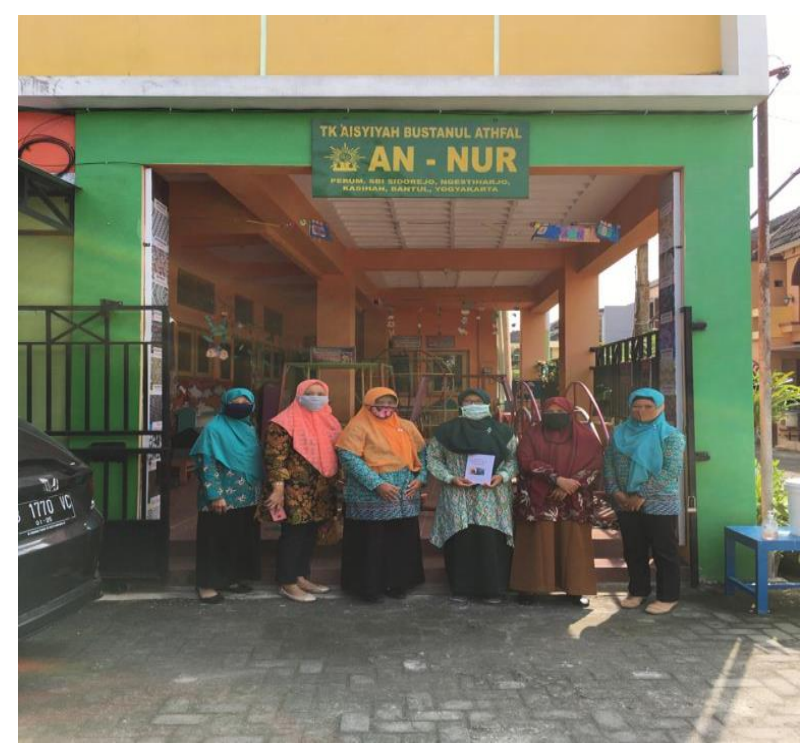

Gambar 2: Koordinasi dengan Kepala Sekolah, Guru TK ABA Annur dan Pelaksanaan IbM

Pemberian informasi menggunakan booklet tentang pencegahan Covid 19 pada anak yang dishare/ dibagikan melalui media whatsapp group wali murid sehingga tidak mendatangkan wali murid ke sekolah. Dimana dalam setiap group tersebut terdapat guru wali kelas dan orang tua wali siswa TK ABA An Nur. Dalam pemberian informasi orang tua wali siswa aktif bertanya untuk hal yang belum diketahui.

Pelaksamaan pengabdian masyarakat secara umum berjalan dengan baik. Untuk peningkatan pengetahuam terdapat peningkatan nilai pre test dan post test yakni dari 47 wali murid mempunyai nilai rata-rata pre test 65 menjadi ratarata 87. Factor pendukung kegiatan ini adalah adanya dukungan yang tinggi dari pihak Sekolah TK ABA An Nur, selain factor pendukung ada juga factor penghambat sedianya informasi akan disampaikan melalui web zoom karena beberapa kendala tidak bisa terlaksana. 


\section{Simpulan}

Kegiatan pengabdian masyarakat promkes pencegahan covid 19 pada anak di TK ABA Annur Bantul Yogyakarta dapat disimpulkan bahwa:

a. Tersedianya booklet promkes pencegahan covid 19 pada anak

b. Terlaksananya pemberian informasi pada wali murid TK ABA Annur.

\section{Ucapan terima kasih}

Terima kasih kami ucapkan kepada Rektor Universitas 'Aisyiyah Yogyakakarta, Ketua LPPM Universitas 'Aisyiyah, Kepala Sekolah, Guru dan Wali Murid TK ABA Annur Bantul dan semua pihak yang telah membantu kelancaran kegiatan ini.

\section{Daftar Pustaka}

Susilowati, Dwi. 2016. Promosi kesehatan. Jakarta: Kementrian kesehatan PPSDMK.

Kemenkes RI. 2011. Promosi kesehatan di Daerah Bermasalah Kesehatan. Jakarta

Machfoedz, Irkham \& Suryani, Eko. 2005. Pendidikan kesehatan Bagian dari Promosi Kesehatan. Yogyakarta: Fitramaya.
Bramasta. Kenali Tanda dan Gejala Infeksi Virus Corona pada Anak-anak. 28 Maret 2020. https://www.kompas. com/tren/read/2020/03/28/100200665/k enali-tanda-dan-gejala-infeksi-viruscorona-pada-anak-anak?page=all. 12 April 2020.

Firdaus Fitra. "Update Corona Indonesia 12 April 2020 \& Data COVID-19 Dunia Terbaru." tirto.id 12 April 2020: https://tirto.id/update-corona-indonesia12-april-2020-data-covid-19-duniaterbaru-eMJS.

KEMENKES RI. Direktorat Jenderal Pencegahan dan Pengendalian Penyakit. Jakarta, 2019.

-. PEDOMAN KESIAPSIAGAAN MENGHADAPI CORONAVIRUS DISESASE (COVID-19). Jakarta, 2020.

Lestari. Penularan Virus Corona pada Anak-Anak, Orangtua Wajib Tahu. 15 Maret 2020. https://www. sehatq.com/artikel/penularan-viruscorona-pada-anak-anak-orangtua-wajibtahu. 12 April 2020.

WHO. coronaviruses (COVID-19). 2020. 